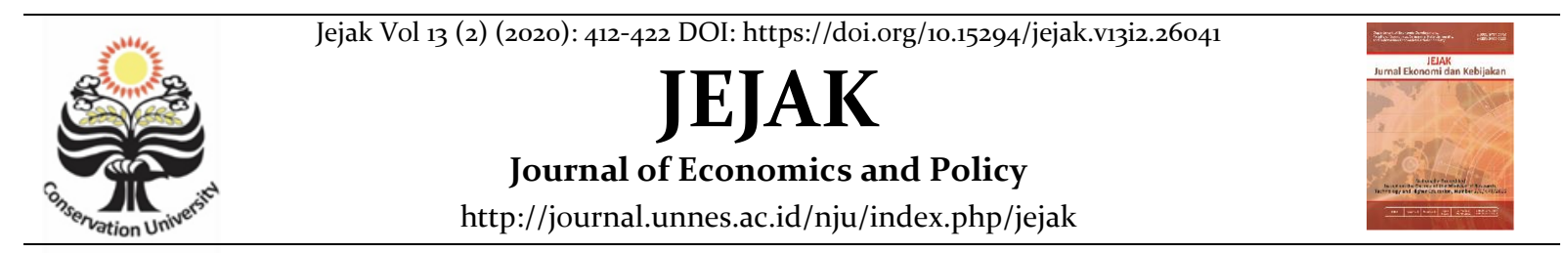

\title{
Technology Absorption as a Main Indicator of Global Entrepreneurship Performance
}

\author{
P. Eko Prasetyo ${ }^{1 凶}$ \\ ${ }^{1}$ Faculty of Economics, Universitas Negeri Semarang \\ Permalink/DOI: https://doi.org/10.15294/jejak.v13i2.26041 \\ Received: May 2020; Accepted: July 2020; Published: September 2020
}

\begin{abstract}
In the globalization era, technology absorption capacity is increasingly vital to own to improve the performance of entrepreneurial industry. The aim of this study was to elaborate the main role of technology absorption as the main determinant to boost the performance of global entrepreneurship. For the sake of analysis, the researchers took primary data from global entrepreneurship index (GEIINDEX, 2019) containing 137 countries that have been surveyed (Acs, 2019). The method of analysis used was path analysis model in recursive form derived from the experimental model of multiple regression method in form of ordinary least square (OLS). The results showed that technology absorption (TA) positively and significantly became the main determinant in improving the capacity and performance of global entrepreneurship, while the opportunity start-up (OS) was the supporting determinant. Shortly, the entrepreneurial industry should have the capacity of technology absorption and mastery to start a business (OS), improve capacity (ABT), and sustainably encourage the excellence of Global Entrepreneurship Performance (GEP).
\end{abstract}

Key words : Technology absorption, Opportunity start-up, Global entrepreneurship performance.

How to Cite: Prasetyo, P. E. (2020). Technology Absorption as a Main Indicator of Global Entrepreneurship Performance. JEJAK: Jurnal Ekonomi dan Kebijakan, 13(2). doi:https://doi.org/10.15294/jejak.v13i2.26041

\footnotetext{
$\triangle$ Corresponding author : P. Eko Prasetyo

Address: Jl. Kampus Timur, Sekaran, Gunung Pati, Semarang

City, Central Java 50229

p-ISSN 1979-715X

E-mail: pekoprasetyo@mail.unnes.ac.id

e-ISSN 2460-5123
} 


\section{INTRODUCTION}

Globalization and technology absorption in Europe and Central Asia have been the leading study in Economics considering that technology absorption has been a necessary step to promote the development of human resources, production and innovation bases (Goldberg, 2008). Nowadays, modern economic business sectors are demanded to have basic and strong Information and Communication Technology (ICT) in order to have the excellent, resilient, and sustainable global competitive performance. Regarding these circumstances, technology absorption (TA) and opportunity start-up (OS) are considered as 2 important dimensions of business capacity in modern economic fields as well as capital human capacity and competition (Acs, 2019; Prasetyo, 2020a).

Furthermore, transfer and diffusion of new technology and value chain capacity in absorbing and mastering technology are increasingly crucial for entrepreneurial industry in this modern era (Acs, 2019; Prasetyo, 2020a, 2020b). Even though the entrepreneurship performance relatively seems similar, its configuration of pillars is different (Acs, 2019). Acs (2019) elaborate the similarities, including risk acceptance, cultural support, technology absorption, and process innovation score which are very similar in three groups of countries (Acs, 2019). Thomas (2014) recommends the implication of relevant policies with technology and entrepreneurship that arise from diffusion model to be deeply investigated and concluded.

In recent years, the diffusion capacity of absorption and ICT mastery have been the initial opportunity to start a business in the modern era. This is necessary to boost business operations and strategies and stimulate innovation and sustainable growth performance of industrial entrepreneurship. Arunachalam, 2018; Acs, 2019; Kim, 2019; Prasetyo, 2020c; Choi, 2020 have conducted empirical studies by investigating the role of technology start-up that affects the quality and innovative performance through technology innovation acts. The results of Choi (2020) also highlight the quality of work as an innovative performance driver in technology start-up and provide implications of practical policies for the improvement of entrepreneurship performance.

Theoretically, after beyond the Solow model or known as the new growth theory, technology as a variable has often been studied as endogeneous and exogeneous factors that influence the performance of industrial entrepreneurship in improving the capacity of competitive performance and the economic growth of a country (Bailetti, 2012; Huang, 2012; Morales, 2014; Badzinska, 2016; Agri, 2018; Prasetyo, 2019, 2020d). Recently, entrepreneurship and technology have often been debated, including debates about industrial launch and growth, regional economic growth, the selection of right stakeholders who are able to deliver ideas into market, and education of manager, engineers and scientists (Bailetti, 2012). Henceforth, technology and industrial entrepreneurship are the indispensable sources of competitive excellences for industrial organization since both of them are able to provide development and exploit new opportunities (Morales, 2014).

The aforementioned variables and indicators are more like the realization of direct measurement from technology transfer or technology absorption than changes in productivity. However, this measurement has weaknesses in reflecting the study of the industrial entrepreneurship performance since it is not obscured by changes in industrial entrepreneurship market environment that coincides with new technology absorption which affects the level of productivity and economic growth (Goldberg, 2008). This 
condition is described in figure 1 that shows the most important mechanism (channels) of technology absorption in each country, entrepreneurship level and industrial companies. Related to this study, figure 1 represents the main focus part as the basic theory of this study.

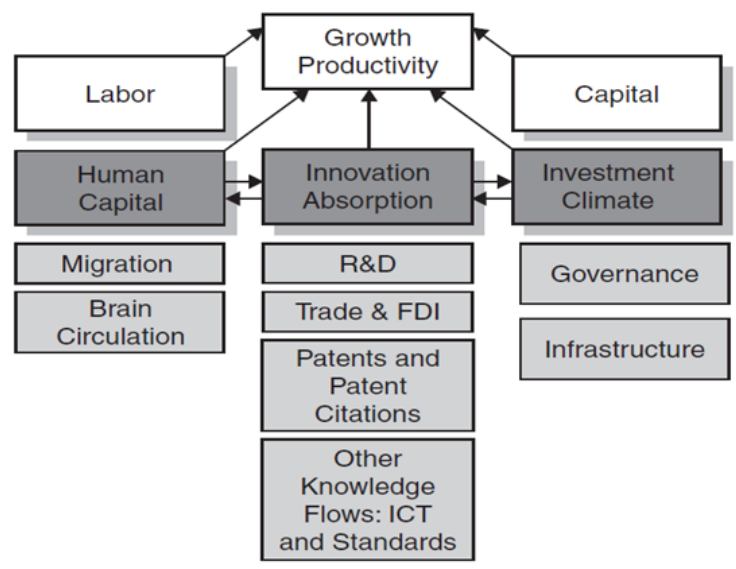

Source: Goldberg, 2008

Figure 1. Innovation and technology absorption as the inputs for development and productivity

Previous related studies have analyzed technology transfer and deeply focused on technology absorption to overcome technological gaps, eliminate the local obstacles, optimize role of institutions, regulation, and bureaucracy, and smoothen the assimilation and dissemination of climate technology in Africa. As Olawuyi's (2018) recommends the framework of technology absorption should be managed for the sake of accelerating the spread of climate technology in larger and sustainable scale in the world. For more, Acs (2019) has a conducted global research about entrepreneurship ecosystem and global entrepreneurship. This research considered entrepreneurship and technology as important mechanisms that encourage the growth of economy through job vacancies, innovation, and welfare. However, the mechanism does not present the path that the countries should pass through stages of development (Acs, 2019).

The research of Mao (2020) explains that the innovation of technology benefits communities by improving communication and productivities in supply chain. This research also recommends the future researches to consider welfare as the main determinant in deciding whether certain technology should be promoted to increase the value for social importance (Mao, 2020). In addition, Atiase (2020) argues technology absorption in Africa has been leading and handles main supporting system for its development, business competition, strategies, and survival. In his study, the variables of technology absorption and human capital index turn into outcomes and explanatory variables.

Based on the explanation above, the objective of this study was to explain the process of innovative technology absorption and assessment of its effectiveness in encouraging the performance of global entrepreneurship. Due to this objective, the novelty and description of findings in this article become significant. The urgency of main problems was how the capacity of absorption and ICT mastery encouraged the improvement of competitive performance of global entrepreneurship. Meanwhile, the specific purpose of this study was to explain the main role of technology absorption (TA) as the main determinant in the improvement of competitive performance of global entrepreneurship. Then, the obtained novelty was in form the best path of mechanism that will provide more ability to encourage the improvement of competitive performance of global entrepreneurship.

\section{METHOD}

Viewed from the main purpose and data type of this study, this study was designed to be a descriptive quantitative research with the 
approach of experimental technique and used multiple regression model in OLS form. Previously, several best models have been chosen as a tool for analysis. The steps covered examining various experimental methods with the model of multiple regression in form of OLS and determining a recursive path analysis model along with its correlational system model design.

By utilizing advances in technology and ICT, the data which have been searched, collected, compiled and archived by the researchers became easier to be accessed for the sake of the future studies by the researchers or others. Consequently, the access of available big data for the purpose of research can be easy, open, and reasonable (Johnston, 2014; Martins, 2018). Similarly, the source of primary data of this study came from the secondary data of Global Entrepreneurship Index (GEINDEX), GEDI, and RIERC (Acs, 2019) in which the big data of GEINDEX was used by the researchers as a dimensional measurement for the variable of Global Entrepreneurship Performance (GEP) variable. This GEP variable has captured various indicators and contextual features of global entrepreneurship performance by focusing on three main pillars of entrepreneurship, namely; Entrepreneurial Attitudes (ATT), Entrepreneurial Abilities (ABT), and Entrepreneurial Aspirations (ASP).

In performing this research, there were several initial steps carried out by the researchers. First, measuring the research design of GEP variable construction and naming it as GEINDEX (Acs, 2019). Second, integrating this index into the design of entrepreneurial performances in 137 countries as samples, and 31 variables, including 17 from GEM dimension and 14 from other data sources which further narrowed into 14 pillars and 3 sub super indexes (Acs, 2019). There were only 3 dimensions analyzed in the experimental design model. Third, the determining research model.

Once the research model was determined, other steps were carried by the researchers. First, the use of GEI big index score by Acs (2019) for the measurement dimension of GEP variable. This index This index score was applied to only one pillar dimension, namely entrepreneurial capacity performance (ABT). Second, the sub dimension of capacity unit was divided into several sub units considered as factor inputs, including technology absorption (TA), human capital (HC), opportunity start-up (OS), and competition (Cpt). Third, the measuring the dimension of factor input main resources using index model or ratio value based on the original source (Acs, 2019).

TA variable was operationally considered as ICT which played significant roles in the economic development. In this case, TA variable was a benchmark of businesses in technological sector and a measurement ratio for the level of capacity of entrepreneurship in a particular country to absorb and master technology in the level of industrial companies as reported by World Economy Forum or known as Global Entrepreneurship Monitor (GEM). The value of TA score index obtained from diffusion ratio, technology transfer and absorption capacity, innovation, and high growth potential. Its index score ranged from 0 to 1 , and the higher the score the better the index is (Acs, 2019).

Operational Start-up (OS) variable was operated as motivation for entrepreneur to start a business and its quality. The higher motivation, the better quality will be. For more, this motivation is realized by the percentage of entrepreneurial business activities, covering business establishment and ability to take advantages of good opportunities, effort to increase income or personal purposes compared to people who have no entrepreneurial opportunities. Institutionally, the level of service effectiveness is measured by variable of 
Good Governance and total management cost and taxes obtained (Acs, 2019).

$\mathrm{HC}$ variable was considered as the input of high qualified human resources which was significantly important for entrepreneurship, highly innovative and also required educated, experienced, and healthy workforce to sustainably grow. HC variable was considered as the ratio of the level of education, market absorption, managerial skill and abilities, innovation, business development and high growth (Acs, 2019). In contrast, Competition ( $\mathrm{Cpt}$ ) was a variable utilized as a dimension to measure new products effectiveness that might be produced or market uniqueness resulted from the combination of market forces in entrepreneurship businesses. This variable measurement dimension is developed by GEM (Acs, 2019)

To analyze the data, this study used path analysis as the main analysis technique. This technique was derived from the experimental method with multiple regression in form of recursive system of OLS. However, the material specifications included in this experiment were not used frequently. Despite of this limitation, this method enables readers to perfect this research. To make it more understandable, the path analysis was arranged to be a mathematic structural equation system model built from mathematical function equation model of OLS multiple regression model with recursive system. The reason of choosing path analysis was due to the ease of obtaining standard coefficient value and meeting the research objectives through direct, indirect, and total path mechanism.
In short, the mathematical function equation is presented as follows

$$
\begin{aligned}
& \mathrm{OS}=\mathrm{f}(\mathrm{TA}, \mathrm{HC}, \mathrm{Cpt}) \\
& \mathrm{ABT}=\mathrm{f}(\mathrm{OS}, \mathrm{TA}, \mathrm{HC}, \mathrm{Cpt}) \\
& \mathrm{GEP}=\mathrm{f}(\mathrm{OS}, \mathrm{TA}, \mathrm{HC}, \mathrm{Cpt}) \\
& \mathrm{GEP}=\mathrm{f}(\mathrm{ABT}, \mathrm{OS}, \mathrm{TA}, \mathrm{HC}, \mathrm{Cpt})
\end{aligned}
$$

Based on equation above, the structural equation system of the chosen path analysis model is as follows.

$$
\begin{aligned}
& \mathrm{OS}=\mathrm{p}_{\mathrm{OS}} \cdot \mathrm{TA}+\mathrm{p}_{\mathrm{Os}} \cdot \mathrm{HC}+\mathrm{p}_{\mathrm{O} s} \cdot \mathrm{Cpt}+\varepsilon_{1} \\
& \mathrm{ABT}=\mathrm{p}_{\mathrm{ABT}} \cdot \mathrm{OS}+\mathrm{p}_{\mathrm{ABT}} \cdot \mathrm{TA}+\mathrm{p}_{\mathrm{ABT}} \cdot \mathrm{HC}+ \\
& \mathrm{p}_{\mathrm{ABT}} \cdot \mathrm{Cpt}+\varepsilon_{2} \\
& \mathrm{GEI}=\mathrm{p}_{\mathrm{GEI}} \mathrm{OS}+\mathrm{pGEI} \cdot \mathrm{TA}+\mathrm{p}_{\mathrm{GEI}} \cdot \mathrm{HC}+ \\
& \mathrm{p}_{\mathrm{GEI}} \cdot \mathrm{Cpt}+\varepsilon_{3} \\
& \mathrm{GEI}=\mathrm{p}_{\mathrm{GEI}} \cdot \mathrm{ABT}+\mathrm{p}_{\mathrm{GEI}} \mathrm{OS}+\mathrm{p}_{\mathrm{GEI}} \cdot \mathrm{TA}+ \\
& \mathrm{p}_{\mathrm{GEI}} \cdot \mathrm{HC}+\mathrm{p}_{\mathrm{GEI}} \cdot \mathrm{Cpt}+\varepsilon_{\$}
\end{aligned}
$$

To obtain the expected the description and mechanism of potential path, this article presents path analysis diagrams in figure 2 and figure 3 along with its values based on the equation number 5 up to 8 .

\section{RESULTS AND DISCUSSION}

In this modern era, advanced technology, the quality of human resources, creativity, innovation, and internet infrastructure are important and highly needed to improve productivity, economic growth, and performance of sustainable competitive excellences. Therefore, the absorption and mastery of technology become major requirements to the utilization of technology and innovation because opportunity start-up is not enough to be supported by human capital resources. 
Table 1. The Role of Technology Absorption on Opportunity Start-up and Entrepreneurial Capacity Performance

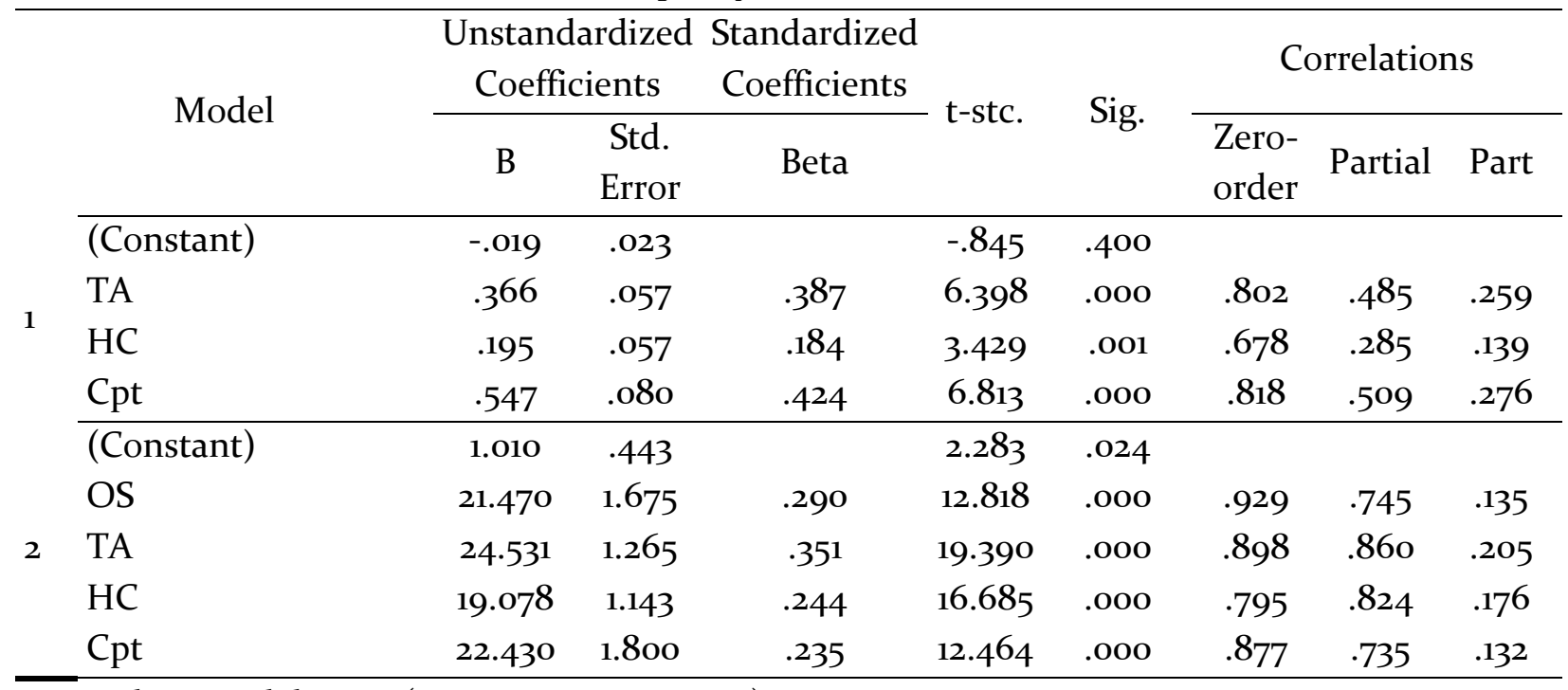

Dependent model-1: OS (Opportunity Start-up)

Dependent model-2: ABT (Entrepreneurial Abilities)

Source: Acs (2019); processed

The global entrepreneurial competition in this modern era is getting stiff. The findings in table-1 indicate that the standardized coefficient value of competition variable (Cpt) was 42.4 , meaning that the opportunity start-up of a new entrepreneurial business must meet reach the competition percentage of 42.4 percent. In addition, the highest standardized coefficient value in both model 1 and model 2 was achieved by TA variable, namely 38.7 percent and 35.1 percent, meaning that when an entrepreneurial business has started its business (in model 1), it still needs the role of technology absorption and human capital quality to survive from the stiff competition. Meanwhile in model 2, when an entrepreneurial business has started to sustainably improve the capacity, it should be able to have factor inputs of technology mastery and absorption capacity as the main driver determinant.

Apparently, the results of this study confirm the previous research conducted by Nasiri (2020) about the role of smart technology. This research was investigated
280 small and medium enterprises (SMEs) in Finland. It shows that digital transformation of entrepreneurship and industrial companies cannot improve the performance of good relation, so it should be combined with smart technology to reach the goals of competitive excellences. Again, the results of this study are also in accordance with Atiase (2020) who revealed that technology absorption and human capital index are supporting each other and being outcome and explanatory variables in improving competitive performance. Furthermore, the path mechanism system of this study is well described in figure 2.

Above all, the researchers noted that the capacity of human capital role to start a business (opportunity start-up) and improve the capacity of entrepreneurship capacity (ABT) and Global Entrepreneurship Performance (GEP) is still highly required. It can be seen from the significant increase in the demand of human capital from model-1 to model-2. This way proved that the findings of this research consistently support the previous ones that human capital capacity the main determinant of entrepreneurship growth and competitiveness 
(Prasetyo, 2020d). This phenomenon is likely to occur either theoretically and empirically because to perform technology absorption and mastery, a business needs the quality of human capital as a fundamental foundation, while other variables only provide supporting function. In brief, the results of this study confirmed that human capital was the basic foundation, while technology absorption was the main determinant and supporter in improving the productivity and performance of entrepreneurship competitive excellences.

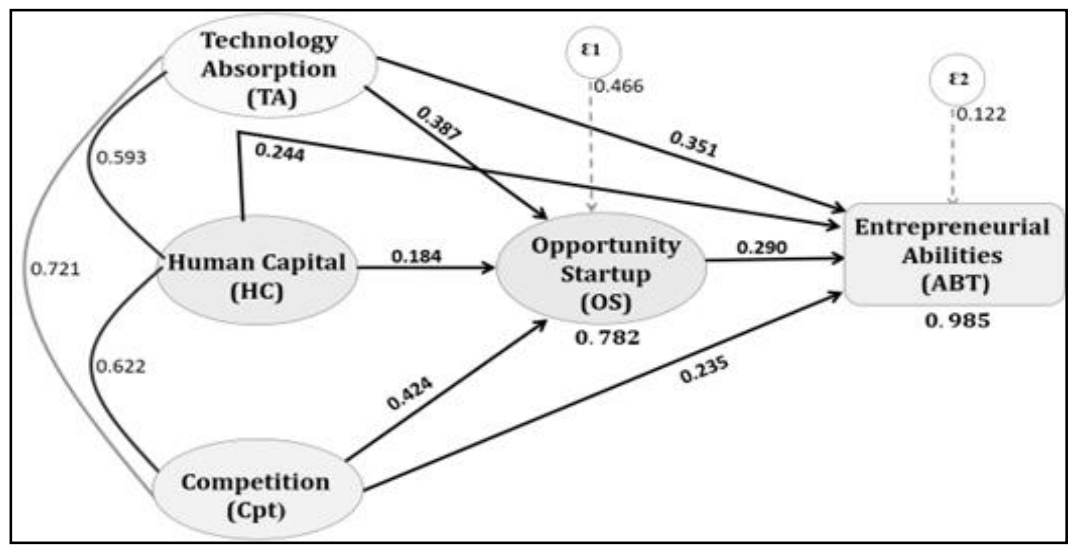

Source: Primary data

Figure 2. The Mechanism of Technology Absorption and Human Capital Roles in Entrepreneurship Capacity

As seen in figure 2, the path of mechanism clearly shows the consistency of starting a new entrepreneurship. Surely it needed competitive capacity, human capital quality, and technology absorption as factor inputs. Additionally, another important thing to realize was that whether the factors of entrepreneurship capacity were able to boost the performance of global entrepreneurship excellences or not. Table $2 \& 3$, figure $3 \& 4$ provide the answer of it.

Table 2. The Path Analysis Results of Global Entrepreneurship Performance Improvement

\begin{tabular}{|c|c|c|c|c|c|c|c|c|}
\hline & \multirow[t]{2}{*}{ Model } & \multicolumn{2}{|c|}{$\begin{array}{c}\text { Unstandardized } \\
\text { Coefficients }\end{array}$} & \multirow{2}{*}{$\begin{array}{l}\text { Standardized } \\
\text { Coefficients } \\
\text { Beta }\end{array}$} & \multirow[t]{2}{*}{ t-stc. } & \multirow[t]{2}{*}{ Sig. } & \multicolumn{2}{|c|}{ Collinearity Statistics } \\
\hline & & $\mathrm{B}$ & Std. Error & & & & Tolerance & VIF \\
\hline \multirow[t]{5}{*}{3} & (Constant) & 4.069 & .926 & & $4 \cdot 393$ & .000 & & \\
\hline & OS & 24.298 & 3.505 & .345 & 6.932 & .000 & .218 & 4.594 \\
\hline & TA & 22.491 & 2.648 & .338 & 8.495 & .000 & .341 & 2.930 \\
\hline & $\mathrm{HC}$ & $15 \cdot 410$ & 2.393 & .207 & 6.440 & .000 & .523 & 1.912 \\
\hline & Cpt & $17 \cdot 302$ & 3.766 & .191 & $4 \cdot 594$ & .000 & .313 & 3.195 \\
\hline \multirow[t]{6}{*}{4} & (Constant) & 2.460 & .615 & & 4.001 & .000 & & \\
\hline & ABT & 1.593 & .119 & 1.673 & 13.424 & .000 & .015 & 67.834 \\
\hline & OS & -9.895 & 3.420 & -.141 & -2.893 & .004 & .097 & 10.313 \\
\hline & TA & -16.576 & 3.383 & -.249 & -4.900 & .000 & .089 & 11.276 \\
\hline & $\mathrm{HC}$ & -14.973 & 2.748 & -.201 & -5.449 & .000 & .168 & 5.943 \\
\hline & Cpt & -18.420 & 3.619 & -.203 & -5.090 & .000 & .144 & 6.955 \\
\hline
\end{tabular}

Dependent model-3 and model-4; GEP (Global Entrepreneurial Performance)

Source: Acs (2019); processed 
Table 2 clearly and consistently shows that the role of TA factor was able to give the second largest contribution after OS in model- 3 and ABT in model-4. The critical note is that when compared to the findings in table-1, it is noticed that technology absorption was able to the main determinant to start entrepreneurship business (OS), improve the entrepreneurial capacity (ABT), or enhance the performance of Global Entrepreneurship Performance (GEP) excellences. The comprehensive elaboration of this finding can be seen in the following figure.

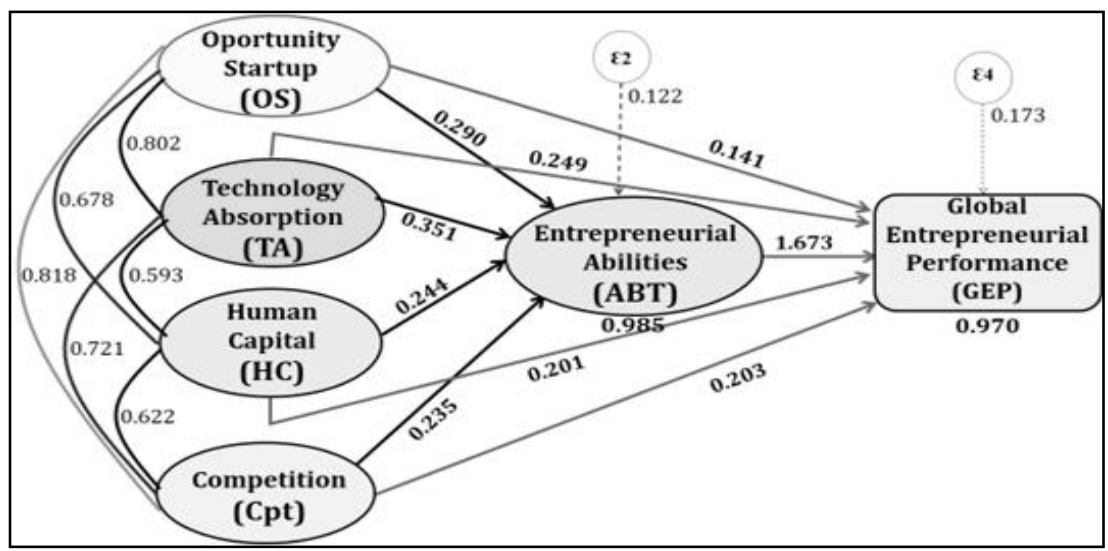

Source: Primary data

Figure 3. The Mechanism of Technology Absorption Roles in Improving Global Entrepreneurial Performance

Once again, this study made a critical note regarding the possible results which may be obtained when the findings data model of model-1 in table-1 and model- 3 in table 3 were combined in one path mechanism model. This way would obtain direct path information about the roles of (TA) factor on (OS) and (GEP). Also, it would result a path mechanism as presented in figure-3, showing that the role of TA factor remained consistent as the main determinant to start a business, improve capacity, or the performance of global entrepreneurial competition excellences collectively. Shortly, TA has positively been the main determinant to improve the performance of global. It is because the absence of technology absorption and mastery would complicate entrepreneurs to start their businesses, and as a result, it will be difficult for them to have a capacity as well as global competitive performance.

Principally, figure 4 determines whether technology absorption still consistently controls GEP or not since the role of this factor has answered the main research problem and objectives of this study as mentioned in figure-1 and figure- 3 as well as table-3. Table 3 recapitulates the evidences of TA role that can provide great, total, direct, and indirect contribution on GEP. 


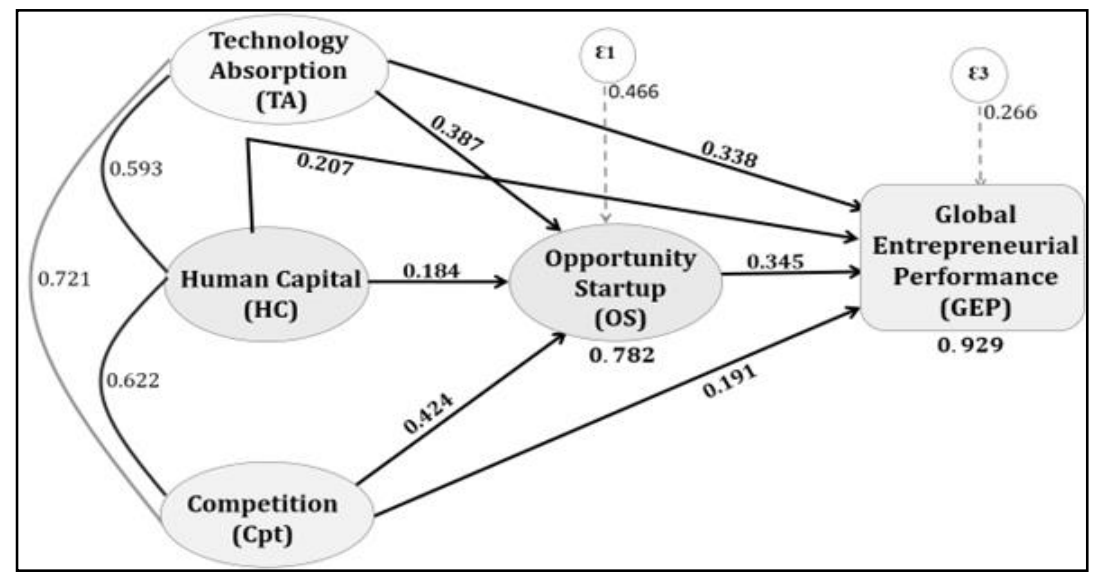

Source: Primary data

Figure 4. The Mechanism of Technology Absorption to Start a Business and Enhance Global Entrepreneurship Performance (GEP)

Table 3. Total, Direct, and Indirect Global Entrepreneurial Performance (GEP)

\begin{tabular}{lcccccccc}
\hline \multirow{2}{*}{ Variable } & Regression & Direct & \multicolumn{7}{c}{ Indirect Effect } & Total \\
\cline { 5 - 8 } & Coefficient & Effect & OS & TA & HC & Cpt & Total & Effect \\
\hline OS & 0.141 & 0.020 & & 0.028 & 0.019 & 0.023 & 0.070 & 0.090 \\
TA & 0.249 & 0.062 & 0.028 & & 0.030 & 0.036 & 0.094 & 0.156 \\
HC & 0.201 & 0.040 & 0.019 & 0.030 & & 0.025 & 0.074 & 0.114 \\
Cpt & 0.203 & 0.041 & 0.023 & 0.036 & 0.025 & & 0.084 & 0.125 \\
\hline Total Effect & & & & & & & & 0.485 \\
\hline
\end{tabular}

Source: Figure-3 and Table-2

Findings in table 3 inform that the role of TA as the main determinant of the improvement of global entrepreneurial competitive performance has been significant. However, it was relatively small and depended on human capital capacity factor. If the quality of human capital in absorbing technology is continuously getting better, the technology absorption will also be getting better in encouraging the business capacity and global entrepreneurship competitive performance. The results of this study proved that good technology absorption was important due to its capacity to encourage business capacity and performance of global entrepreneurship competition. However, its capacity still depended on the quality of human capital as human resources factor existed in a particular country in which, at the end could absorb technology and collectively start an entrepreneurship business and improve the entrepreneurship performance capacity.

The recapitulation of critical notes elaborated that the mechanism model in figure 3 was the most complete path mechanism and able to provide greatest contribution in improving the performance of business competition through the dimension of entrepreneurship capacity improvement. However, the researchers found its weakness by referring to its negative contribution in table-3 and model-4. Even though the negative number on path analysis model does not have any effect because of the positive value it obtains after being quadrated, different and misleading understanding may occur when researchers perform simple multiple regression analysis. 
Hence, based on the critical notes, the best and consistent path mechanisms in this model were those in table-1, figure-2, and figure-4. Actually, if the results of model-4 were not negative, figure 3 seemingly became the best model considering its path analysis model.

\section{CONCLUSION}

It is undeniable that the capacity of technology absorption is getting important and highly necessary in this modern era. The results of this study conclude that the capacity of technology absorption and mastery become the main determinant in improving the capacity and performance of global entrepreneurial competitive excellences both directly and indirectly. In addition, the results of this study also provide strong contribution and support the new growth theory of Solow model. Technology positively becomes the main determinant in improving economic development of a country. Therefore, the implication of practical policy to be carried out by government is to keep improving the capacity of human capital factor in technology absorption so that the growth and performance of global entrepreneurship can improve.

\section{REFERENCES}

Agri, E.M., Kennedy, N.D., Bonmwa, G.O., \& Acha, O.F. (2018). Technology Innovation and Sustainable Entrepreneurship Development in Nigeria: Stakeholders' Impact Assessment in Central Nigeria, Journal of Economics, Management and Trade, 21(3), 1-16.

Arunachalam, S.; Ramaswami, S.; Herrmann, P.; Walker, D. (2018). Innovation pathway to profitability: The role of entrepreneurial orientation and marketing capabilities. Journal of the Academy of Marketing Science, 46, 744766.

AtiAE, V.Y., Dzansi, D.Y. \& Ameh, J.K. (2020). Technology absorption capacity and firm growth in Africa. View project, 341655891.

https://www.researchgate.net/publicatio $\mathrm{n} /$

Atiase, V.Y., Dzansi, D.Y., \& Ameh, J.K. (2020). Technology absorption capacity and firm growth in Africa. ResearGate, 343041337. https://www.researchgate.net/publicatio $\mathrm{n} /$

Badzińska, E. (2016). The Concept of Technological Entrepreneurship: The Example of Business Implementation. Entrepreneurial Business and Economics Review, 4(3), 57-72. doi: 10.15678/EBER.2016.040305.

Bailetti, T. (2012). Technology Entrepreneurship: Overview, Definition, and Distinctive Aspects. Technology Innovation Management Review, 2, 5-12.

Choi, D.S., Sung, C.S., \& Park, J.Y (2020). How Does Technology Start-ups Increase Innovative Performance? The Study of Technology Start-ups on Innovation Focusing on Employment Change in Korea. Sustainability, 12 (551), 1-14.

Goldberg, I., Branstetter, L., Goddard, J. G., \& Kuriakose, S. (2008). Globalization and Technology Absorption in Europe and Central Asia The Role of Trade, FDI, and Cross-border Knowledge Flows. World Bank Working Papers, No. 150. 1818 H Street, N.W.: Washington, D.C. 20433, U.S.A. doi: 10.1596/978-0-8213-7583-9

Huang, K. (2011). Technology competencies in competitive environment. Journal of Business Research, 64(2), 172-179.

Johnston, M.P. (2014). Secondary Data Analysis: A Method of which the Time Has Come. 
Qualitative and Quantitative Methods in Libraries, 3, 619-626.

Kim, J., \& Yoo, J. (2019). The Efects of Entrepreneurial Orientation and Environmental Uncertainty on Korean Technology Firms' R\&D Investment. Journal of Open Innovation: Technology Market Complexity, 5(29), 1-13.

Mao, C., Koidea, R., Bremb, A., \& Akenjia, L. (2020). Technology foresight for social good: Social implications of technological innovation by 2050 from a Global Expert Survey. Technological Forecasting $\mathcal{E}$ Social Change, 153 .

Martins, F. S., \& da-Cunha, A. C. (2018). Secondary Data in Research Uses and Opportunities. Journal of Strategic Management, 17(3), 1-5.

Morales, V.J.G., Ramos, M.T.B., \& Rojas, R.M. (2014). Technological variables and absorptive capacity's influence on performance through corporate entrepreneurship. Journal of Business Research, 67, 1468-1477.

Nasiri M., Ukko, J., Saunila, M., \& Rantala, T. (2020). Managing the digital supply chain: The role of smart technologies. Technovation, 96-97(2020), 102-121.

Olawuyi, D.S. (2018). From Technology Transfer to Tehnology Absorption Addressing Climate Technology Gaps in Africa. Journal of Energy $\mathcal{E}$ Natural Resources Law, 36(1), 61-84. doi: https://doi.org/10.108o/o2646811.2017.1 379667.

Prasetyo, P.E., \& Siswantari, H. (2020a). Technology Absorption in Entrepreneurial Aspirations and Capabilities. International Journal of Innovation, Creativity and Change, 14(3), 1264-1277.
Prasetyo, P. E. (2020b). Attitudes, Aspirations and Entrepreneurial Capabilities: Key Dimensions of Entrepreneurial Performance [Sikap, Aspirasi dan Kemampuan Wirausaha: Dimensi Utama Kinerja Kewirausahaan]. Journal of Management and Entrepreneurship, 8(2), 1-12.

Prasetyo, P. E., \& Dzaki, F.Z. (2020c). Institutional performance and new product development value chain for entrepreneurial competitive advantage. Uncertain Supply Chain Management, $8(4), 561-576$.

Prasetyo, P. E., \& Kistanti, N. R. (2020d). Human capital, institutional economics and entrepreneurship as a driver for quality \& sustainable economic growth. Entrepreneurship and Sustainability Issues, 7(4), 2575-2589.

Prasetyo, P. E. (2019). The Reliability of Entrepreneurial Productivity as Driver of Economic Growth and Employment. International Journal of Entrepreneurship, 23(4), 1-15.

Thomas, B. (2014). A Model of the Diffusion of Technology into SMEs. ResearchGate, 255587273. Retrived from https://www.researchgate.net/publicatio $\mathrm{n} /$ 